\title{
Knowledge and Oral Hygiene Practice by School Children in Cox's Bazar, Bangladesh.
}

\author{
Dr. Mohammad Nazmul Kabir ${ }^{1 *}$, Dr. Md. Bashir Ahmed², Dr. Mahbuba Khan ${ }^{3}$
}

\section{AFFILIATION:}

1. Dr. Mohammad Nazmul Kabir BDS, DDS, BCS (Health) Assistant Professor, Dentistry,

Cox's Bazar Medical College, Cox's Bazar.

2. Dr. Md. Bashir Ahmed

BDS, BCS (Health)

Dental surgeon, 250 bed general hospital, Cox's bazar.

3. Dr. Mahbuba Khan

Private Practitioner, Popular Mouchak Hospital, Gazipur

\section{Article info.}

Received: $1^{\text {st }}$ January, 2019

Accepted: $15^{\text {th }}$ March, 2019

Volume: 9, Issue-2 October, 2019

\section{DOI: https://doi.org/10.3329/updcj.v9i2.43736}

(C) Authors retain copyright and grant the journal right of first publication with the work simultaneously licensed under Creative Commons Attribution License CC - BY 4.0 that allows others to share the work with an acknowledgment of the work's authorship and initial publication in this journal.

https://creativecommons.org/licenses/by/4.0/

Publisher: Update Dental College, Dhaka, Bangladesh

Web: www.updatedentalcollege.edu.bd

E-mail: updcj@hotmail.com
* Corresponding Author

Dr. Mohammad Nazmul Kabir BDS, DDS, BCS (Health)

Assistant Professor, Dentistry, Cox's Bazar Medical College, Cox's Bazar. E-mail: drmdnazmulkabir@gmail.com Cell: 01712776618

\begin{abstract}
Background: A healthy mouth enables people to eat, speak and socialize without pain, discomfort or embarrassment. The Oral cavity is a portal of entry and the site for microbial infections that affect overall health status; Oral diseases are one of the most prevalent diseases, endangering our health and safety. Objectives: the objective of this study was to identify oral hygiene practiced by school children in Cox's Bazar, Bangladesh Methods: A descriptive cross-sectional study carried out among 474 students of class IX of at randomly selected Schools in Cox's Bazar, Bangladesh. The samples were collected by purposive sampling technique and a structured questionnaire considering objectives of the study was used to collect data, Data were collected by faceto-face interview of the students, SPSS software (version 19) was used to analyze the data, and descriptive statistics and chi-square test were done. Results: Maximum, $\{274(57.8 \%)\}$ children brushed their teeth every day at age of 5 to 10$)$ years, and $233(49.2 \%)$ children Brushed their teeth at morning and night, Relationship between age and oral hygiene practice is statistically significant ( $P$ value 0.03$)$. Male and female are relatively same in oral hygiene practice. Most of $\{438(92.4 \%)\}$ the children clean teeth with tooth brush and tooth paste, 243(51.3\%) children used tooth brush in upward and downward direction. Conclusion: Age, parents' education, teachers, others personnel's and media are important factors to motivate the children to maintain oral hygiene regularly, property and using teeth cleaning devices and materials.
\end{abstract}

\section{KEY WORDS: \\ Oral hygiene practice, School children}

\section{INTRODUCTION:}

Oral health is a state of being free from chronic mouth and facial pain, oral and throat cancer, oral sores, birth defects Such as cleft lip and palate, periodontal disease, tooth decay and tooth loss, and other diseases and disorders that affect the oral cavity. Risk factors for oral diseases include poor oral hygiene, unhealthy dict. tobacco and alcohol use. A healthy mouth enables people to eat, speak and socialize without pain, discomfort or embarrassment. The oral cavity is a portal of entry and the site for microbial infections that affect overall health status. Oral diseases are one of the most prevalent diseases, endangering our health and safety Neglecting oral hygiene can cause caries, toothache, and loss of teeth which could lead to disability of chewing, and speech, orthodontic problems und TMJ disorders. Poor oral health might have a profound effect on general health. Bacteria from the oral cavity can be aspirated into the lung to cause respiratory diseases such as pneumonia, especially in people with periodontal disease. People with periodontal disease are almost twice as likely to suffer from coronary artery disease as these without periodontal disease. There is association between human periodontal disease and certain system disorders such as diabetes mellitus, pneumonia, heart disease and pre-term birth.

Plaque largely is made up of commensal species in the mouth Dental plaque formations involve an ordered pattern of
Dr. Mohammad Nazmul Kabir, Dr. Md. Bashir Ahmed, Dr. Mahbuba Khan, Knowledge and Oral Hygiene Practice by School Children in Cox's Bazar, Bangladesh. Update Dental College Journal. 2019 October; 9(2):27-31 DOI: https://doi.org/10.3329/updcj.v9i2.43736 
colonization by many different bacteria. The accumulation of plaque is considered a complex and multifactor process overall The changes in the specific composition and quantity of plaque alter its potential to cause periodontal and dental problems. The most common procedure to remove dental plaque involves using a toothbrush and toothpaste. Although using a toothbrush significantly improves the level of adequacy of oral hygiene, there are many other contributing factors, such as dental flossing and mouth rinsing etc.

Children who have dental caries in their primary dentition are more likely to have dental caries in permanent dentition. Growing children need proper guidance for healthy growth, upkeep and hygiene of their teeth. Permanent teeth erupt during the school age years. Good dental hygiene and regular attention to dental caries are

Vital parts of health supervise during this period Correct brushing techniques and the role of fermentable carbohydrates that play in production of dental caries should be taught or reinforced. The objective of this study was to identify oral hygiene practice patterns among schoolchildren,

\section{METHODS:}

A descriptive cross-sectional study was carried out among the students of randomly selected different schools at Cox's Bazar in Bangladesh. The study was conducted from January 2018 to June 2018 among 474 students of class I to class X. The samples were collected by purposive sampling technique. In order to collect the data a structured questionnaire and a checklist was prepared at the beginning of the study considering all objectives and variables of the study. Data were collected by the researcher through face- to-face interview of the students and by oral examination. SPSS software package (version 19) was used to analyze the data. Descriptive statistics were used for all variables. Values were expressed as percentage and chisquare test was done. According to the objectives and variables of the study the results were presented in the form of tables and graphs.

\section{RESULTS:}

Among children, maximum, [279(58.9\%)] were 5 to 10 years; male $(50.4 \%)$ and female $(49.6 \%)$ were about same and regarding parent's education level $133(28.1 \%)$ were higher educated and $19(4 \%)$ were literate (Figure-1)

Maximum, $[274(57,8)]$ children Brushed their teeth every day at age of 5 to 10 Years (table-1) from 5 to 10 years age, $123(25.9 \%)$ children and above 10 years age, 112(23.6\%) children brushed their teeth twice daily (table- II). Total 233(49.2\%) children brushed their teeth at morning and night among them, 119(25.1\%) children from 5 to 10 year age and $112(23.6 \%)$ are above 10 year age (table-III). Total 207(43.7\%) children brushed their teeth for 3 minutes. Among them 124 (26.2\%) children from 5 to 10 year age and 78 (16.5\&) children are above to year age 10 year age (table-IV) Relationship between age and oral hygiene practice is statistically 28| P a g e significant; $P$ value $<0.05$.

Among the males, $232(48.9 \%)$ children brushed their teeth every day (table-V), 111(23.4\%) children brushed their teeth twice daily (table- VI), 110(23.2\%) children brushed their teeth at morning and night (table-VII), 101(21.3\%) children brushed their teeth for 3 minutes (table-VIII).

Table I: Distribution of children according to teeth brushing in relation to age $(n=474)$

\begin{tabular}{|c|c|c|c|c|c|}
\hline \multirow[t]{2}{*}{ Age } & & \multicolumn{2}{|c|}{ Teeth Brushing } & \multirow[t]{2}{*}{ Total } & \multirow[t]{2}{*}{ P Value } \\
\hline & & Everyday & $\begin{array}{l}\text { Some } \\
\text { times }\end{array}$ & & \\
\hline \multirow{2}{*}{$\begin{array}{l}\text { Up to } 5 \\
\text { yrs }\end{array}$} & $\mathrm{n}$ & 23 & 0 & 23 & \multirow[t]{8}{*}{0.01} \\
\hline & $\%$ & 4.9 & 0 & 4.9 & \\
\hline \multirow{2}{*}{$\begin{array}{l}5 \text { to } 10 \\
\text { yrs }\end{array}$} & $\mathrm{n}$ & 274 & 5 & 279 & \\
\hline & $\%$ & 57.8 & 01.1 & 58.9 & \\
\hline \multirow{2}{*}{$\begin{array}{l}\text { Above } \\
10 \text { yrs }\end{array}$} & $\mathrm{n}$ & 165 & 7 & 172 & \\
\hline & $\%$ & 34.8 & 1.5 & 36.3 & \\
\hline \multirow[t]{2}{*}{ total } & $\mathrm{n}$ & 462 & 12 & 47.4 & \\
\hline & $\%$ & 97.5 & 2.5 & 100 & \\
\hline
\end{tabular}

$\mathrm{P}$ value reached from $\boldsymbol{x}^{2}$ test

Table II: Distribution of children according to relationship between age and frequency of teeth brushing $(a=474)$

\begin{tabular}{|c|c|c|c|c|c|c|}
\hline \multicolumn{2}{|c|}{ Age } & \multicolumn{4}{|c|}{ How Many Time Brushing } & \multirow{2}{*}{$\begin{array}{l}\text { P } \\
\text { Value }\end{array}$} \\
\hline & & Once & Twice & Thrice & Total & \\
\hline \multirow{2}{*}{$\begin{array}{l}\text { Up to } 5 \\
\text { yrs }\end{array}$} & $\mathrm{n}$ & 21 & 2 & 0 & 23 & \multirow[t]{8}{*}{0.083} \\
\hline & $\%$ & 4.4 & 4 & 0 & 4.9 & \\
\hline \multirow{2}{*}{$\begin{array}{l}5 \text { to } 10 \\
\text { yrs }\end{array}$} & $\mathrm{n}$ & 140 & 123 & 16 & 279 & \\
\hline & $\%$ & 29.5 & 25.9 & 3.4 & 58.9 & \\
\hline \multirow{2}{*}{$\begin{array}{l}\text { Above } \\
10 \text { yrs }\end{array}$} & $\mathrm{n}$ & 50 & 112 & 10 & 172 & \\
\hline & $\%$ & 10.5 & 23.6 & 2.1 & 36.2 & \\
\hline \multirow[t]{2}{*}{ total } & $\mathrm{n}$ & 211 & 237 & 26 & 474 & \\
\hline & $\%$ & 44.5 & 50 & 5.5 & 100 & \\
\hline
\end{tabular}

P value reached from $z^{2}$ test

Table III: Distribution of children according to relationship between age and frequency of teeth brushing $(n=474)$

\begin{tabular}{|c|c|c|c|c|c|c|c|c|}
\hline \multirow[t]{2}{*}{ Age } & & \multicolumn{6}{|c|}{ How Many Time Brushing } & \multirow{2}{*}{$\begin{array}{l}\mathbf{P} \\
\text { Valu } \\
\text { e }\end{array}$} \\
\hline & & $\begin{array}{c}\text { Befo } \\
\text { re } \\
\text { Brea } \\
\mathbf{k} \\
\text { Fast }\end{array}$ & $\begin{array}{c}\text { Afte } \\
\mathbf{r} \\
\text { Brea } \\
\mathbf{k} \\
\text { Fast }\end{array}$ & $\begin{array}{c}\text { Befo } \\
\text { re } \\
\text { Bed }\end{array}$ & $\begin{array}{c}\text { Afte } \\
\mathbf{r} \\
\text { Ever } \\
\mathbf{y} \\
\text { Mea } \\
\mathbf{l}\end{array}$ & $\begin{array}{l}\text { Morni } \\
\text { ng and } \\
\text { Night }\end{array}$ & $\begin{array}{l}\text { Tot } \\
\text { al }\end{array}$ & \\
\hline \multirow{2}{*}{$\begin{array}{l}\text { Up } \\
\text { to } 5 \\
\text { yrs }\end{array}$} & $\mathrm{n}$ & 21 & 0 & 0 & 0 & 2 & 23 & \multirow{8}{*}{$\begin{array}{l}0.09 \\
6\end{array}$} \\
\hline & $\%$ & 4.4 & 0 & 0 & 0 & 4 & 4.9 & \\
\hline \multirow{2}{*}{$\begin{array}{l}5 \text { to } \\
10 \\
\text { yrs }\end{array}$} & $\mathrm{n}$ & 142 & 2 & 2 & 14 & 119 & 279 & \\
\hline & $\%$ & 30.0 & 4 & 4 & 3 & 25.1 & 58.9 & \\
\hline \multirow{2}{*}{$\begin{array}{l}\text { Abov } \\
\text { e 10 } \\
\text { yrs }\end{array}$} & $\mathrm{n}$ & 49 & 1 & 0 & 10 & 112 & 172 & \\
\hline & $\%$ & 10.3 & 2 & 0 & 2.1 & 23.6 & 36.2 & \\
\hline \multirow[t]{2}{*}{ total } & $\mathrm{n}$ & 212 & 3 & 2 & 24 & 233 & 474 & \\
\hline & $\%$ & 44.7 & 6 & 4 & 5.1 & 49.2 & 100 & \\
\hline
\end{tabular}

$\mathrm{P}$ value reached from $z^{2}$ test 


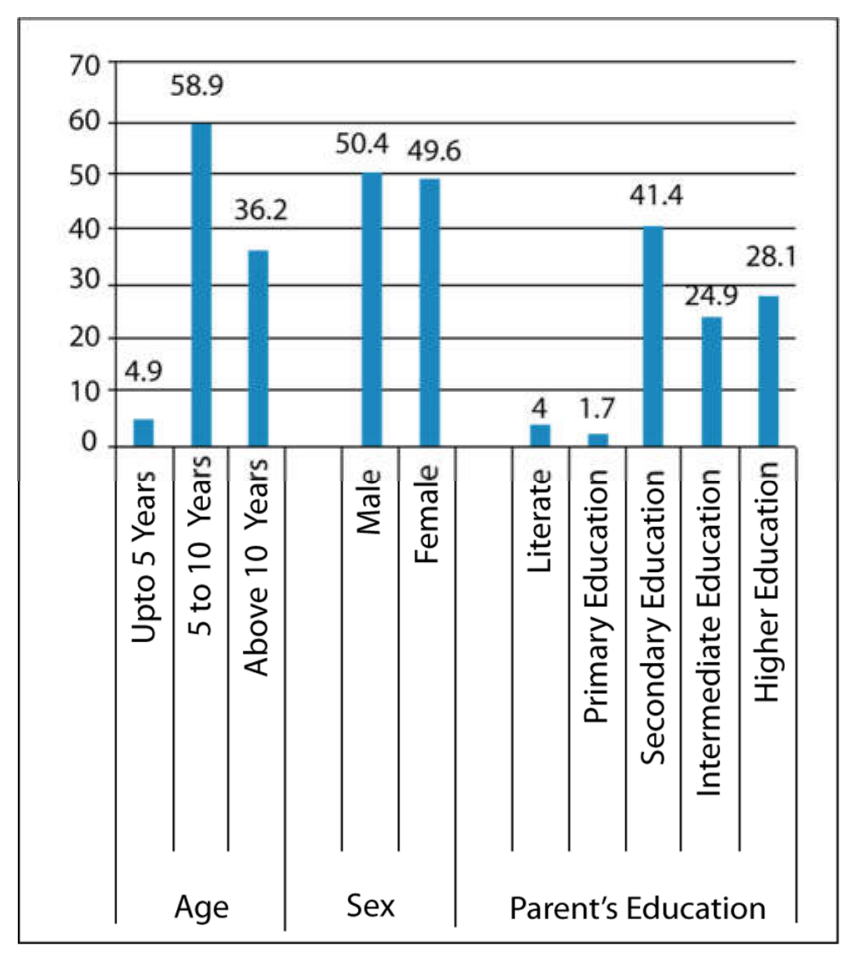

Figure-1: Socio-Demographic Status of the Children

Table IV: Distribution of children according to relationship between age and duration of teeth Brushing $(n=474)$

\begin{tabular}{|c|c|c|c|c|c|c|}
\hline \multirow[t]{2}{*}{ Age } & & \multicolumn{3}{|c|}{ Brushing Duration } & \multirow[t]{2}{*}{ Total } & \multirow[t]{2}{*}{ P Value } \\
\hline & & 1 to $2 \mathrm{~min}$ & $3 \mathrm{~min}$ & $>3 \mathrm{~min}$ & & \\
\hline \multirow[t]{2}{*}{ Up to 5 yrs } & $\mathrm{n}$ & 14 & 5 & 4 & 23 & \multirow[t]{8}{*}{0.019} \\
\hline & $\%$ & 3 & 1.1 & 8 & 4.9 & \\
\hline \multirow[t]{2}{*}{5 to 10 yrs } & $\mathrm{n}$ & 95 & 124 & 60 & 279 & \\
\hline & $\%$ & 20 & 26.2 & 12.7 & 58.9 & \\
\hline \multirow[t]{2}{*}{ Above 10 yrs } & $\mathrm{n}$ & 34 & 78 & 60 & 172 & \\
\hline & $\%$ & 7.2 & 16.5 & 12.7 & 36.3 & \\
\hline \multirow[t]{2}{*}{ total } & $\mathrm{n}$ & 143 & 207 & 124 & 474 & \\
\hline & $\%$ & 30.2 & 43.7 & 26.2 & 100 & \\
\hline
\end{tabular}

$\mathrm{P}$ value reached from $\boldsymbol{x}^{2}$ test

Table V: Distribution of children according to relationship between age and duration of teeth brushing $(n=474)$

\begin{tabular}{lcllll}
\hline \multirow{2}{*}{ Sex } & & \multicolumn{2}{l}{ Teeth Brushing } & Total & \multirow{2}{*}{ P Value } \\
\cline { 2 - 5 } & & Everyday & Some times & & \\
\hline \multirow{2}{*}{ Male } & $\mathrm{n}$ & 232 & 0 & 239 & \multirow{2}{*}{0.001} \\
\cline { 2 - 5 } Female & $\%$ & 48.9 & 0 & 50.4 & \\
& $\mathrm{n}$ & 230 & 5 & 235 \\
\cline { 2 - 5 } Total & $\%$ & 48.5 & 01.1 & 49.6 & \\
& $\mathrm{n}$ & 462 & 7 & 474 \\
\hline
\end{tabular}

$\mathrm{P}$ value reached from $\boldsymbol{x}^{2}$ test
Table VI: Distribution of children according to teeth brushing in relation to age $(n=474)$

\begin{tabular}{|c|c|c|c|c|c|c|}
\hline \multicolumn{2}{|c|}{ sex } & \multicolumn{4}{|c|}{ How Many Time Brushing } & \multirow[t]{2}{*}{ P Value } \\
\hline & & Once & Twice & Thrice & Total & \\
\hline \multirow[t]{2}{*}{ Male } & $\mathrm{n}$ & 113 & 111 & 15 & 239 & \multirow[t]{6}{*}{0.036} \\
\hline & $\%$ & 23.8 & 23.4 & 3.2 & 50.4 & \\
\hline \multirow[t]{2}{*}{ Female } & $\mathrm{n}$ & 98 & 126 & 11 & 235 & \\
\hline & $\%$ & 20.7 & 26.6 & 2.3 & 49.6 & \\
\hline \multirow[t]{2}{*}{ Total } & $\mathrm{n}$ & 211 & 237 & 26 & 474 & \\
\hline & $\%$ & 44.5 & 50 & 5.5 & 100 & \\
\hline
\end{tabular}

$\mathrm{P}$ value reached from $\boldsymbol{x}^{2}$ test

Table VII: Distribution of children according to relationship between age and frequency of teeth brushing $(n=474)$

\begin{tabular}{|c|c|c|c|c|c|c|c|c|}
\hline \multicolumn{2}{|c|}{ Age } & \multicolumn{6}{|c|}{ How Many Time Brushing } & \multirow{2}{*}{$\begin{array}{l}\text { P } \\
\text { Value }\end{array}$} \\
\hline & & $\begin{array}{c}\text { Befor } \\
\text { e } \\
\text { Break } \\
\text { Fast }\end{array}$ & $\begin{array}{c}\text { After } \\
\text { Brea } \\
\mathbf{k} \\
\text { Fast }\end{array}$ & $\begin{array}{l}\text { Befor } \\
\text { e Bed }\end{array}$ & $\begin{array}{c}\text { After } \\
\text { Ever } \\
\text { y } \\
\text { Meal }\end{array}$ & $\begin{array}{l}\text { Mornin } \\
\text { g and } \\
\text { Night }\end{array}$ & $\begin{array}{l}\text { Tota } \\
\text { I }\end{array}$ & \\
\hline \multirow[t]{2}{*}{ Male } & $\mathrm{n}$ & 113 & 1 & 2 & 13 & 110 & 239 & \multirow{6}{*}{$\begin{array}{l}0.03 \\
6\end{array}$} \\
\hline & $\%$ & 23.8 & 2 & 4 & 2.7 & 23.2 & 50.4 & \\
\hline \multirow{2}{*}{$\begin{array}{l}\text { Femal } \\
\text { e }\end{array}$} & $\mathrm{n}$ & 99 & 2 & 0 & 11 & 123 & 235 & \\
\hline & $\%$ & 20.9 & 0.4 & 0 & 2.3 & 25.9 & 49.6 & \\
\hline \multirow[t]{2}{*}{ Total } & $\mathrm{n}$ & 212 & 3 & 2 & 24 & 233 & 474 & \\
\hline & $\%$ & 44.7 & 6 & 4 & 5.1 & 49.2 & 100 & \\
\hline
\end{tabular}

$\mathrm{P}$ value reached from $z^{2}$ test

Table VIII: Distribution of children according to relationship between sex and duration of teeth brushing $(n=474)$

\begin{tabular}{|c|c|c|c|c|c|c|}
\hline \multirow[t]{3}{*}{ Age } & & \multicolumn{3}{|c|}{ Teeth Brushing } & \multirow[t]{3}{*}{ Total } & \multirow[t]{3}{*}{ P Value } \\
\hline & & 1 to $2 \mathrm{~min}$ & 3 & $>3$ & & \\
\hline & & & $\min$ & $\min$ & & \\
\hline \multirow[t]{2}{*}{ Male } & $\mathrm{n}$ & 76 & 101 & 62 & 239 & \multirow[t]{6}{*}{0.01} \\
\hline & $\%$ & 16 & 21.3 & 13.1 & 50.4 & \\
\hline \multirow[t]{2}{*}{ Female } & $\mathrm{n}$ & 67 & 106 & 62 & 235 & \\
\hline & $\%$ & 14.1 & 22.4 & 13.1 & 49.6 & \\
\hline \multirow[t]{2}{*}{ total } & $\mathrm{n}$ & 143 & 13.1 & 124 & 474 & \\
\hline & $\%$ & 30.2 & 49.6 & 26.2 & 100 & \\
\hline
\end{tabular}

$\mathrm{P}$ value reached from $\boldsymbol{z}^{2}$ test

Among the females, $230(48.5 \%)$ children brushed their teeth every day (table-V), 126(26.6\%) children brushed their teeth twice daily (table-V1), 123(25.9\%) children brushed their teeth at morning and night (table-VII) und 106(22.4\%) children brushed their teeth for 3 minutes (table-VII), Relationship between sex und oral hygiene practice is statistically significant; $P$ value 0.05 . Among the children, 438(92.4\%) children clean their teeth with tooth brush, 417(92.4\%) used tooth pest during teeth brushing: 186(39.2\%) used tooth brush in forward and backward direction, 243(51.3\%) used tooth brush in upward and downward direction.

Among the children, $115(24.3 \%)$ used normal stick. 160(33 8\%) used tooth pick, 19(4\%) used thread, 23(4.9\%) used dental floss for inter dental cleaning. Among the children, 462(97.5\%) are taught tooth brushing from their parents, $10(2.1 \%)$ are taught tooth brushing from their teacher and 2(0.4\%) are taught tooth brushing from their dentist (figure-2). 
Figure 2: Distribution of children according to uses of oral hygiene aids.

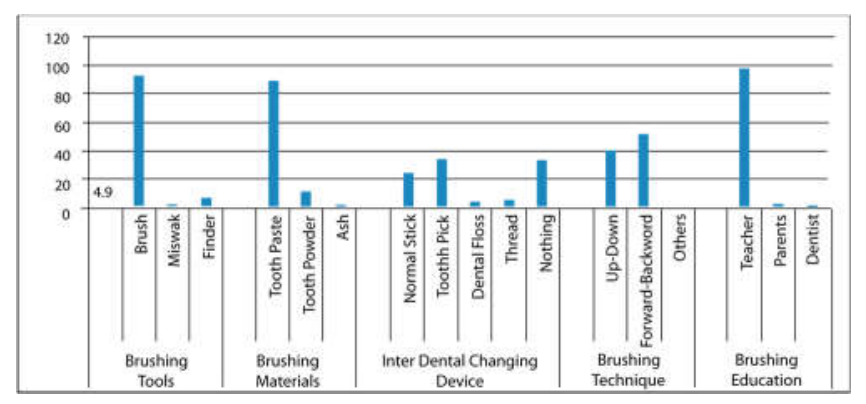

\section{DISCUSSION:}

By socio- demographic status, maximum (38.9\%) children's were 5 to 10 years old, among them male and female were same. And education level of maximum, (41.4\%) children's parents were secondary and literate were minimum (4\%). A study", conducted on Bangladeshi primary school! children, $51.98 \%$ children were male and $47.97 \%$ were children female; and age of the children's was from 6 to 13 years Another study" was conducted on Bangladeshi school going rural children, total 350 children's were included in the study age ranging from 10 to 15 years, among them $45.71 \%$ were male and $54.29 \%$ were female. These study result is similar to the present study.

In the study it is found that most of the children brushed their teeth every day and twice daily at age of 5 to 10 years, and above 10 years age, maximum children brushed their teeth of morning and night for 3 minutes: Age is an Important factor for maintaining oral hygiene, as increasing the age children can realize the importance's of care of teeth. Khan" conducted a study on 3-12 years old 646 children in Swat, Pakistan and found border line significant in relationship of age and oral hygiene maintenance

This study found no significant differences between male and female in regularly, frequency, time and duration of tooth brushing. Similar result is found in another study by Take and Juan', Mia et all* found male children are significantly higher in regularity, frequency, time and duration of tooth brushing. This variation may be due to geographical variation as they collected sample from Cox's Bazar district there are socioeconomic and environmental variation between two districts. The differences may be also due to technique of sample collection as they selected the school by two-stage cluster sampling design

The present study found $92.4 \%$ children clean their teeth with tooth brush and tooth paste. This result is supported by Mia et al who found most of the respondents use tooth brush and pest to clean their teeth.

The results differ from another study by Sarwar et $\mathrm{al}^{22}$ who found that $33.2 \%$ were using tooth brush and $12 \%$ were using tooth paste and rest of the respondents clean teeth using

30 | P a g e finger, branch of teeth, and ash. Tooth powder and charcoal. These differences between due to as they conducted the study in rural area. Maximum (51.3\%) children used tooth brush in upward-downward direction and rest of the children brush teeth in faulty direction. Most (97.5\%) of the children are taught tooth brushing from their parents and rest of the respondents taught tooth brushing from others. Similar result found in the study by Mia et al. Parents, teachers and others personnel's and media are important factors to motivate the children to maintain oral hygiene.

\section{CONCLUSION:}

Age is an important factor for maintaining oral hygiene. As increasing the age children can realize the importances of care of teeth and they emphasize on oral hygiene maintenance Sex has no significances on oral hygiene practice. Most of the children clean their teeth with tooth brush and tooth pest. Use of finger, branch of tree, ash, tooth powder and charcoal are less amount. Parents, teachers and others personnel's and media are important factors to motivate the children to maintain oral hygiene.

\section{REFERENCES:}

1. World Health Organization. Health topics: oral health. www.who.int topics/oral_health/en/ (accessed 27 October 209)

2. Kwan S, Petersen PE, Pine CM, Bonatia A. Health-promoting schools un opportunity for oral health promotion, Hull WHO DOS; B39): B7T-BS.

3. Antora MK, Syed M A Oral and dental health in a low-income rural community in Bangladesh. Research and Evaluations Division, BRAC, Dhaka, Bangladesh; March 2011 (working Paper 90.20)

4. Namjoye Nick K. Dental canes in Iranian pupils and importance of prevention. Majallan- I- Dandanpiczishki JIDAL 1984: 9

5. Afshar H, Exshadi A, Ershodi M. An Investization on the Correlationbetween DMFT and OHE- S Indices on 12- Year- Old School Girls m Kashan J Dent 2004: $1(-1538-42$

6. de Oliveira C, Watt BR. Momer M_ Toothbrushing, inflammation and risk of cardiovascular disease: results from Scottish Health Survey. Br Med J 2010 340362451.

7. Juan JV. Carlo E M, Gerardo M. Ana A V, Laura Land Marco VP Socioeconomic and Sock to demographic Variables Associated With Oral Hygiene Status in Mexican School children Aged 6 to 12 Years 3 Periodontal 21107 ;78:816-22. https://doi.org/10.1902/jop.2007.060324 PMid:17470014

8. Marsh PID. Are dental diseases examples of ecological catastrophes? Microbiology 2003:149:279-04

https://doi.org/10.1099/mic.0.26082-0 PMid:12624191

9. Martens L_ Vanobberpen J, Leroy K_ Lesaflre E, Decterck D. Variables associated with oral hygiene bevels in 7-vear-ohds im Belgiam. Comm Dont Health 2004, 21,4-10

10. van Serydonck DAC, Timmerman MF, van der Velden $U$, van der Werden GA. The ant-plaque efficacy of a chlothexidine moathrines uved in combination with tooth brushing wrth dentifrice. J ClinPerodontol 2004, 31.691-5.https://doi.org/10.1111/i.1600-051X.2004.00546.x

PMid: 15257749

11. Goyal CR, Sharma NC, Quggsh 40. Cugini MA, Thompson MC, Warren PR. Efficacy of a novel brash bead in the companson af two power toothbrashes on removal of plaque and naturally occurrme extemsic stem. J Dent 2005; 33/cSuppl. 137-43

12. Croain MJ, Dembting WZ, Cugini MA, Thompson MC Warren PR. Threemonth assessment of safety and efficacy of two electric tooth brushes. J Dent 2005. 33 (Sappl. 1)23-8.

https://doi.org/10.1016/S0300-5712(05)80004-1

Website: https://www.banglajol.info/index.php/UpDCJ 
13. Sharma NC. Goyal CR, Qugish 40, et al. Single-ase plaque removal efficacy of three power toxhbrushes. J Dent 2005, 33 (Suppl- 1)11-5. https://doi.org/10.1016/50300-5712(05)80002-8

14. abe J. Dental canes and oral hygiene practices of chaldren und caregivers m Kernla, Indes - MDS thesis swhencited to the Univeraty of Hong Kong, Poediatne Deabsiry and Orthodontics, Faculty of Dentistry University of Hong Koag 2001.

15. ismael AL The role of early dietaiy Habits in dental caries development. Spec Care Dent 1998, 18 (1) 40-3

https://doi.org/10.1111/j.1754-4505.1998.tb01357.x

PMid:9791306

16. Kaur 8. Evalusbon of oral health awareness $\mathrm{m}$ parents of preschool children. Indian J Dont Res 200, 20-463-5.

https://doi.org/10.4103/0970-9290.59455 PMid:20139572

17. Mahesh KP. Joseph T, Varma RB, Jayanth: M. Oral health status of S years and 12 years school going children in Chennai cxty - An epidemiological study. J Indian Soe Pedox! Prey Dent 2005, 23: 17-22.

https://doi.org/10.4103/0970-4388.16021 PMid:15858301

18. Misha MP, Hubbard RM. Haque S, Sayeed MA, Imam ST. Khunam PA. Begum T and Khan MH. Gingivitis in Primary School Children Of Bangladesh Ibrahim Med Coll. J. 2009:714

19. Mia MNA, Mia MAQ, Hoque MM Singha RK. Oral hygiene practices among Bangladeshi rural adobescenta, Medici fodaty, 201. 23(2): 72-5 https://doi.org/10.3329/medtoday.v23i2.13099

20. Khan MA Prevalence of Dental Canes Among 3-12-Years- OldChildres of Swat - Pakistan Pakistan Oral \& Dent J 2000, 2H2V321-6

21. Tak M, Nagarajappa R, Sharda A, Asawa K, Tak A, Jalthal S, Comparative assessment of Orul Hygiene and Periodontal stutas among childres who have Polomyelites at Udurpur city, Rajasthan, \{india Med Creal Patol Oral Cir Bucal, 2012: 17 (6)0989-76. https://doi.org/10.4317/medoral.17658

PMid:22549671 PMCid:PMC3505718

22. Sarwar APM, Kabir MH, Rahman APMM_Haqee A, Kasern MA, Ahmad SA, Debnath PK, Mallick PC\Haque M, Hossam KA, Khao SI. Abmed AHHU \&Parveen 8. Oral hygiene practic: among the primary school children im selected mural areas of Banglodest: J. Dhaka Naboeal Med Coll. Hos 2011, 18 (01p43-8 https://doi.org/10.3329/jdnmch.v18i1.12240 